\title{
corporation members of the AMS
}

\section{Contributing Corporation Members}

Accu-Weather, Inc.

Weather Services Corporation

\section{Corporation Members}

Aanderaa Instruments, Inc.

Aerospace Corporation

AG Risk Management, Inc.

AeroVironment Inc.

Air Traffic Services, Civil Aeronautics Administration of the Republic of China

Air Transport Association of America

Air Weather Service Technical Library

Alden Electronics

Argonne National Laboratory

Atmospheric and Environmental Research

Atmospheric Environment Service

AT\&T Federal Systems

Audichron Company, Pastel Division

Bahamas Meteorological Department

Barbados Meteorological Service

Bechtel Power Corporation

Belfort Instrument Company

The Boeing Company

Botswana Meteorological Services

Brock University Library

Calspan Corporation

Caribbean Meteorological Institute

Centro Técnico Aerospacial, Divisao de Ciencias Atmosféricas

Chanute Air Force Base Technical Library

Civil Aviation and Meteorological Authority

Climatronics Corporation

Colorado International Corporation

Colorado State University, Department of Atmospheric Science

Communications and Weather Research Foundation, Inc.

Computer Sciences Corporation

Concurrent Computer Corporation

Contel-Spacecom

Control Data Corporation

Creighton University, Atmospheric Science Program

Curtin University of Technology

Dartmouth College Library

Deutscher Wetterdienst

Dobbie Instruments (Australia) PTY. LTD.

Edinburgh University Library

Electric Power Research Institute

Electronic Data Systems Federal Corporation

Enterprise Electronics Corporation

Environmental Instruments, Inc.

Environmental Satellite Data, Inc.
ERT, Inc.

Ericsson Radio Space Systems AB

E-Systems, Inc., Garland Division

European Organisation for the Exploitation of

Meteorological Satellites (EUMETSAT)

Factory Mutual Engineering Corporation

Fernbank Science Center

Finnish Meteorological Institute

Florida State University, Department of Meteorology

Ford Aerospace and Communications Corporation/

Western Development Laboratories

Freeport International Weather Service

GEOMET Technologies, Inc.

Global Weather Dynamics, Inc.

Gould Inc., Imaging and Graphics Division

HANDAR

Harris Corporation

Harvard University

Illinois State Water Survey

Indian Institute of Tropical Meteorology

Indiana University Library, Serials Department

Input Output Computer Services

Irish Meteorological Service

Israel Embassy

ITT Aerospace/Optical Division

Japan Meteorological Agency, Meteorological College

Kaijo Denki Co., Ltd.

Kavouras/RAM, Inc.

Kaysam Corporation of America

Kean College of New Jersey

Irving P. Krick Associates, Inc.

Lightning Location and Protection, Inc.

Lockheed Dataplan, Inc.

Massachusetts Institute of Technology, Department of Meteorology

Meteophysics Corporation

Met One, Inc.

Metracom Incorporated

Millersville University of Pennsylvania, Dept. of Earth Sciences

Mount Isa Mines Limited

Murray and Trettel Inc., Consulting Meteorologists

National Agency of Environmental Protection, Roskilde, Denmark

National Meteorological Library of the United Kingdom

National Severe Storms Lab.

New Zealand Meteorological Service

North American Weather Consultants

NUS Corporation

OAO Corporation

Oceanroutes, Inc.

The Ohio State University, Atmospheric Sciences Program

Oregon State University, Department of Atmospheric Sciences

Pan Am World Services, Inc.-Eastern Test Range Project 
Pennsylvania State University, Department of Meteorology Pennsylvania State University, Pattee Library

Phillipine Weather Bureau

Planning Research Corporation

Purdue University

Queensland Electricity Generating Board (Australia)

Raytheon Company

RCA Astro-Electronics Division

Republic of Korea Air Force, 73rd Weather Group

Republic of Korea, Meteorological Research Institute

Research Triangle Institute

Rockwell International, Collins Air Transport Division

Rotronic Instrument Corporation

Royal Netherlands Meteorological Institute

Royal Observatory, Hong Kong

Rutgers University, Douglass-Cook Library

Saint Louis University, Department of Earth and

Atmospheric Sciences

San Jose State University, Department of Meteorology

SASC Technologies

Service Argos, Inc.

Service Central D'Exploitation Meteorologique

South Dakota School of Mines and Technology

Space Data Corporation

Swiss Meteorological Institute

Systems Applications, Inc.

Telecommunicacoes Aeronauticas S. A. TASA

Teledyne Geotech

Texas A\&M University, Department of Meteorology

Texas Water Commission

3M, Stormscope Systems

TRADOC Weather and Environmental Support Office

Travelers Insurance Company

Trinidad and Tobago Meteorological Services

TS Infosystems, Inc.

Tycho Technology

United States Naval Academy Library
Universal Weather and Aviation

Università di Bologna, Dipartimento di Fisica

Universität Freiburg, Meteorologisches Institut

Universität Innsbruck, Institut für Meteorologie and Geophysik

Universiti Kebangsaan Malaysia, Library

University Corporation for Atmospheric Research, National Center for Atmospheric Research

University of Arizona, Institute of Atmospheric Physics

University of California, Los Angeles, Department of Atmospheric Sciences

University of Chicago, Department of the Geophysical Sciences

University of Copenhagen, Geophysical Institute

University of Maryland, Department of Meteorology

University of Michigan, Department of Atmospheric and Oceanic Science

University of Nevada, Desert Research Institute

University of North Carolina

University of Northern Colorado Library

University of Oklahoma, Department of Meteorology

University of Sheffield Library

University of Washington, Department of Atmospheric Sciences

US Army Atmospheric Sciences Laboratory

VIZ Manufacturing Company

Weather Bureau, Pretoria, South Africa

The Weather Channel

Weather Consultants Incorporated

Weather Corporation of America

Western Weather Consultants, Inc.

Woods Hole Oceanographic Institution

WSI Corporation

WTVT Television Weather Service

Yale University, Department of Geology and Geophysics

R. M. Young Company

Zephyr Weather Information Service 